\title{
Family literacy programmes in South Africa: Should we take note?
}

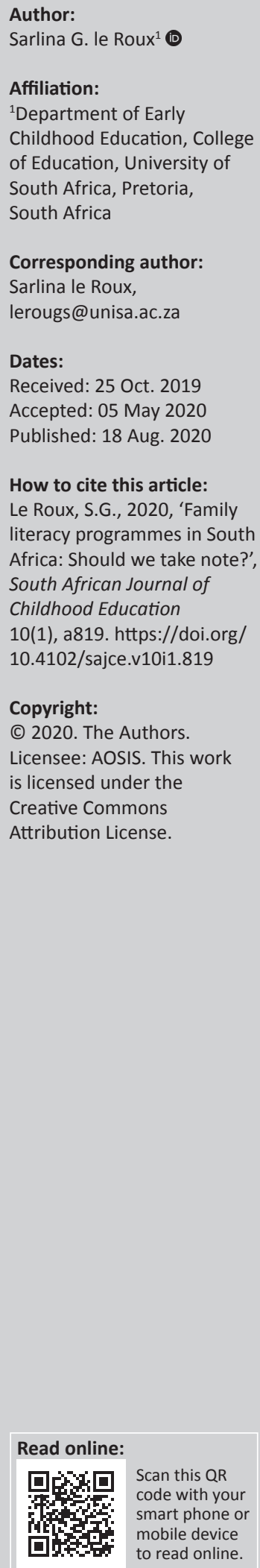

Background: South Africa has one of the lowest-performing education systems in the world. By the fourth grade, many learners are already 2 or more years behind their peers, especially in mathematics and literacy. Family literacy programmes as a form of home-school partnership are often proposed as an early intervention to support early literacy learning. Family literacy programmes remain a new concept in South Africa and little formal research has been undertaken on the nature, availability and implications of such programmes in this country.

Aim: The aim of this article is to investigate family literacy programmes currently running in South Africa by means of a theoretical framework.

Setting: The data presented here are the result of an electronic search comprising books and journal articles for the period 1990-2019.

Methods: For this article, a qualitative analysis was undertaken, using concept analysis as the main data collection technique. Key words such as 'family literacy', 'family literacy programmes', 'intergenerational literacy' and 'home-school partnerships' were used to produce a sample obtained by simple random sampling.

Results: An inductive data analysis approach was followed to identify and discuss programmes that fit the attributes and criteria of family literacy programmes and to make recommendations towards partnership attributes, resource and activity attributes, and future research to clarify implications.

Conclusion: If family literacy programmes are to gain momentum, researchers must continue to unpack what this concept holds to ensure such programmes yield optimal results, not only for participating families, but also for the South African schooling system in general.

Keywords: early childhood education; early intervention; early literacy; emergent literacy; family literacy; family literacy programmes; home environments; home-school collaboration; intergenerational literacy; parent involvement.

\section{Introduction}

According to international assessments in literacy and mathematics, South Africa has one of the poorest-performing education systems in the world (Cohen 2017; Simkins 2013; Van der Berg et al. 2011). In the last decade, the South African Government has shifted its focus to early childhood education (ECE) as a foundation for later academic success. Great strides have been made towards establishing access to pre-school programmes and Grade R (a non-compulsory reception-year programme). In his 2019 State of the Nation address (Republic of South Africa [RSA] 2019a), President Ramaphosa announced that government will (1) migrate ECE centres from the Department of Social Development to the Department of Basic Education (DBE), (2) introduce 2 years of compulsory ECE before Grade 1 and (3) implement substantial improvements to make reading comprehension in the early years a priority. Furthermore, in her 2018/2019 education budget vote speech, the Minister of Basic Education (RSA 2019b) announced that her department was in the process of revising policy that will allow struggling learners to progress through the Foundation Phase (Grades R-3) without having to repeat a grade. According to Spaull and Taylor (2012:4), additional years of schooling will not necessarily improve the capabilities of learners; neither will automatic grade promotion without mastering the necessary skills and competencies improve literacy outcomes. That much is evident, as $78 \%$ of South African fourth graders fail to read with meaning in any language (Howie et al. 2017; Pretorius 2014:61). Van der Berg et al. (2013) warn that allowing a learner to start school earlier, without a targeted intervention, may prove to be unsuccessful. There may be no easy or cheap solutions, and as socio-economic factors play such a significant role in academic performance, it makes sense to evaluate intervention 
programmes that focus on strengthening partnerships between the school and the home. The purpose of this article is to investigate, analyse and describe family literacy programmes currently running in South Africa, to review their benefits to early literacy and make recommendations towards future implementation.

\section{Literature review \\ Development of early literacy skills}

As early as 1693, the British philosopher John Locke (1632-1704) argued that reading instruction should start early in life - in fact, as soon as children learn to talk - but cautioned that it should happen in an informal, playful manner (Berns 2016:138; Locke 2000; McNulty 2014:492). Locke also believed that children learn through imitation and would therefore imitate the reading and writing behaviours and activities of their parents (McNulty 2014:494). In recent years, researchers have confirmed that the development of literacy is a process that starts in the home (Crawford \& Zygouris-Coe 2006:261; Parcel, Dufur \& Zito 2010:828). Today, researchers agree that children engage with reading and writing long before they start school. As children observe other people using literacy in their everyday lives, they learn that reading and writing can be used to get things done (Wasik \& Hermann 2004:5). They begin to experiment, and through pretend reading and writing, learn about literacy and gradually make these practices part of their lives. Neaum (2012:116) regards the moment when children understand the purposes of literacy as the beginning of the reading process, which Wasik and Hermann (2004:6) describe as 'early' or 'emergent' literacy. The relevant emergent literacy knowledge includes awareness of the purposes of literacy, awareness of a story, concepts about print, knowledge of letters and phonological awareness. If children come to school with this knowledge it seems reasonable to infer that they have learned it in the home. If they lack these skills, family literacy programmes may be useful to help them acquire such skills.

\section{Reasons for strengthening family literacy in South Africa}

With an unemployment rate of almost 30\% (Statistics South Africa [StatsSA] 2019), many South African families are negatively affected by poor socio-economic circumstances, including poverty and malnutrition, violence, migrancy and life-threatening diseases such as tuberculosis and human immunodeficiency virus, acquired immunodeficiency syndrome (HIV / AIDS) (Holborn \& Eddy 2011:1). As there is a strong relationship between family literacy practices and academic performance, the situation calls for research into the family literacy practices of South African families. The following factors may also have an impact on literacy development, and ultimately academic success:

- Poor quality of ECE provisioning: A study by Van der Berg et al. (2013) found that the impact of Grade R in South Africa is relatively limited, exerting almost no measurable effect in the poorest schools. Possible reasons include the fact that early childhood practitioners receive limited training and underestimate their role in a child's development.

- Lack of early language and reading experiences (Train 2007:296-297): The erosion of the family environment, compounded by the fact that many children live in households that have no monthly income, negatively affects their social and cognitive development (Rama \& Richter 2007:138). Many families are in survival mode and have little time and few resources to create environments which are conducive to early literacy learning.

- Literacy acquisition in a multicultural and multilingual setting: Although South Africa has 11 official languages (RSA 1996), English has become the preferred language of learning and teaching in schools (Alexander 2005). Consequently, the poor academic performance of black learners especially in this country is often related to the challenge of having to learn in a language other than their home language (Postma \& Postma 2011).

- Intergenerational barriers (Train 2007:296-297): South Africa does not have a reading culture (Mulgrew 2012). Due to historical factors, older people's literacy levels are often very low. Given that many children grow up with their grandparents, exposure to children's literature and rich literacy practices are limited (Amoateng \& Richer 2003:261). Many children from disadvantaged environments have never handled a book, and lack basic knowledge of how to manage and use books, which means they are at a major disadvantage when they start school (Machet \& Pretorius 2004:39).

- Poor basic skills: Parents with poor basic literacy skills lack the confidence to support their own children's literacy learning (Train 2007:296-297).

- Economic and financial barriers: Malnutrition, technological backwardness, being deprived of opportunities and adverse surroundings marked by conflict and violence, substance abuse and crime negatively affect the early development and later school performance of most South African children (Unisa 2008). Poor school performance often leads to an early drop-out from the schooling system, thereby reinforcing an already negative cycle (Stats SA 2013:14). Many children from disadvantaged communities are only exposed to early literacy activities in pre-school or at childcare centres (Pretorius \& Machet 2008:286).

- Cultural barriers: Some communities do not value reading; neither do they embrace reading as a habit. There is also limited children's literature available in African languages. Many of the available texts are translations of stories from a Western culture and context, rather than original African stories in their own languages (Pretorius \& Machet 2008:265).

- Dysfunctional schools: The poorest schools often lack physical resources, are likely to have underqualified teachers with ineffective teaching practices and are often governed inefficiently by the school management team (Pretorius \& Machet 2008:264). In addition, poorer schools have to find ways of supporting learners from families where parents have low education levels, and where few books or other texts are available in the home or even in the community. 
- Common beliefs: Literacy development is often seen as the domain of teachers and schools, rather than something which parents can and should do (Crawford \& ZygourisCoe 2006:262). Many South African teachers view parents as trespassing on their terrain if the latter help their children learn to read (Lemmer \& Van Wyk 2007). This leaves the school and home as distinct and separate entities, with no structure or framework to strengthen their shared responsibilities.

\section{Defining concepts of family, family literacy and family literacy programmes}

Family literacy programmes are based on the belief that young children learn about literacy in their homes and families, and are designed to bridge the gap between home and school learning (Crawford \& Zygouris-Coe 2006:261). The concepts family and parent are also referred to in their broadest sense, as many families are headed by single parents (mostly women), with reconstituted family structures after divorce and remarriage also being common (Berns 2016:60). In the South African context, the extended family plays an important role, as many children are raised by grandparents or other family members (Amoateng \& Richter 2003:261). When referring to family literacy, family may therefore include a grandmother or grandfather, a single mother or father raising children, a foster family, a same-sex family, a child-headed household, or any other familial combination. The term parent is also used in its broadest sense and refers to any adult who cares for, supports and protects a child.

Similarly, many definitions of family literacy can be found in the literature. Jay and Rohl (2005:59) define family literacy as related activities which children engage in, outside of the classroom. These events include a variety of reading, writing, speaking, listening and viewing activities with people of different ages. Such literacy activities are functional and are shaped by the culture and context of the family or community. Wasik (in Wasik, Dobbins \& Hermann 2001:445) has a similar view of family literacy, defining it as a concept that includes all of the literacy practices used within the home, family and community to get things done, and which are only later built on in school.

Family literacy programmes differ in terms of the groups they target, as well as the location. Some programmes focus either on children or on adults; others deal with both (Hannon $\&$ Bird 2004). If the focus is on both groups, there may be separate sessions for each, or both may collaborate in shared activities. The location in which programmes are presented can also vary (Wasik \& Hermann 2004:8, 13): some are carried out in the home; others are implemented at school, in libraries or even in the community (e.g. in a local church). Taylor's (2017:22) evaluation of the large-scale Early Grade Reading Study (EGRS), implemented in South African schools, also assessed parental intervention as one arm of the intervention, and found that parent intervention had a significant positive impact on the development of phonological awareness. However, both Keyser (2006:4) and Lemmer (2013:26) caution that the successful implementation of family literacy programmes is dependent on an equal partnership between practitioners and families, as all families have valuable expertise, skills and resources, and positive aspirations for their children. This is referred to as the 'wealth approach' and requires family literacy educators and providers to identify and build on literacy practices that already exist within families, rather than to impose traditional mainstream, school-like activities on families.

\section{Methods Using concept analysis}

This article is a continuation of an action research inquiry that was done in 2015, in which the author investigated the role of a home-school partnership programme to support the early literacy development of young learners in a South African school. One of the recommendations to emerge from the author's original study (Le Roux 2016) was a need to establish a detailed database of all family literacy programmes, providing a synopsis of the content and structure of all available family literacy programmes. This recommendation prompted a continuation of the investigation to include new literature and new developments up to 2019. The programmes discussed here are the result of a qualitative analysis of the concepts of 'family literacy' and 'family literacy programmes' undertaken by means of a concept analysis. This method can be defined as a process of inquiry that explores concepts as they are revealed by their structure, use, representativeness and relation to other concepts (Rodgers 2000). It is a process of exploring, investigating and understanding concepts, with the aim of developing new concepts or defining, comparing, clarifying, identifying, refining and validating themes. Rodgers (2000:78) define 'concepts' as the 'labels, categories, or selected properties of objects to be studied'. According to Tofthagen and Fagerstrom (2010), this method should not be confused with a literature review, which typically foregrounds an empirical study and aims to assess the status of existing research on a topic.

\section{Identification of the concept}

In the study on which this article is based, the researcher conducted a literature review with content analysis as the main data-collection technique. Definitions and descriptions of family literacy and family literacy programmes in the literature were sought from the existing literature and the Internet, before being carefully explored to uncover their defining attributes.

\section{Identification and selection of an appropriate setting and sample for data collection}

During the original study, an electronic search was carried out of interdisciplinary databases comprising English-only journal articles and books published in the fields of education, sociology and family studies, for the period 1990-2015. To reflect the current state of family literacy programmes in South Africa, the search was later expanded 
to include literature published between 2015 and 2019. Literature dealing with family literacy worldwide, as well as in South Africa, was consulted. Key words such as 'family literacy', 'family literacy programmes', 'intergenerational literacy' and 'home-school partnerships' were used to produce a sample obtained by simple random sampling. As family literacy remains a relatively new concept in this country and as many of the programmes are not well researched, the researcher also relied on the assistance of Desmond, who worked in the field of family literacy and published on the concept (Desmond 2008, 2012). Based on Desmond's assistance and guidance, the electronic search was extended to include an internet search of nongovernmental organisations (NGOs) that offer literacy programmes. The researcher thereafter selectively sampled any programmes that seemed promising and applicable to the local context, with the aim of identifying those with a family literacy component.

\section{Data collection and management}

After selecting the final sample, the documents were downloaded and printed from the electronic databases, organised and labelled by database. An exploration of the data collected demanded multiple readings of the literature, during which the researcher made notes and studied recurring themes and categories, to understand the essential meaning of the concept. The initial reading provided an overview of the articles; during the second and subsequent readings, documents were examined for specific issues, with a view to categorising themes (Rodgers 2000). Constant comparisons were made to enhance simultaneous data collection and analysis.

\section{Data analysis}

As the focus was on identifying family literacy programmes operating in South Africa, an inductive data analysis approach was used, in which the researcher sought to identify common applications of the concept. The tests of sufficiency and necessity were applied throughout; sufficiency refers to the relevance of elements related to the true meaning of a concept, whilst necessity refers to an examination of attributes of the concept, to determine whether or not they apply to dissimilar concepts. The data were then categorised under the following rubrics, as proposed by Rodgers (2000): antecedents and surrogate terms, attributes, context and consequences or implications (Table 1). Triangulation of the data was ensured by means of telephonic conversations with several of the directors of the NGOs, through which local family literacy programmes are implemented. Two of them were kind enough to make their programme content available to the researcher.

\section{Review findings}

As Desmond (2012) indicates, initiatives to support family literacy in South Africa are not well documented. Furthermore, many programmes do not define themselves as
TABLE 1: Analysis of family literacy programmes according to Rodgers' criteria.

\begin{tabular}{|c|c|c|c|}
\hline $\begin{array}{l}\text { Antecedents and } \\
\text { surrogate terms }\end{array}$ & Attributes & Context & $\begin{array}{l}\text { Consequences/ } \\
\text { Implications for practice }\end{array}$ \\
\hline $\begin{array}{l}\text { Home-school } \\
\text { partnership }\end{array}$ & $\begin{array}{l}\text { - Focus (out of } \\
\text { school literacy } \\
\text { learning, family } \\
\text { literacy activities, } \\
\text { intergenerational } \\
\text { literacy, informal } \\
\text { literacy learning at } \\
\text { home, functional } \\
\text { literacy) }\end{array}$ & $\begin{array}{l}\text { - Independent } \\
\text { (NGO-driven, } \\
\text { self-funded) }\end{array}$ & $\begin{array}{l}\text { - Improved literacy } \\
\text { learning of young } \\
\text { children }\end{array}$ \\
\hline $\begin{array}{l}\text { - Parent } \\
\text { involvement }\end{array}$ & $\begin{array}{l}\text { - Activities } \\
\text { (comprehensive } \\
\text { programmes, } \\
\text { workshops, } \\
\text { modelling activities, } \\
\text { home visits) }\end{array}$ & $\begin{array}{l}\text { - Government- } \\
\text { mandated } \\
\text { (policy-driven, } \\
\text { government- } \\
\text { funded) }\end{array}$ & $\begin{array}{l}\text { - Improved parenting } \\
\text { for literacy }\end{array}$ \\
\hline $\begin{array}{l}\text { - Parental } \\
\text { support }\end{array}$ & $\begin{array}{l}\text { - Groups targeted } \\
\text { for change: adults, } \\
\text { children, both } \\
\text { (shared or separate) }\end{array}$ & & $\begin{array}{l}\text { Improved interaction/ } \\
\text { communication } \\
\text { between parents and } \\
\text { children }\end{array}$ \\
\hline - Social capital & $\begin{array}{l}\text { - Location of } \\
\text { meetings: Home/ } \\
\text { school/community }\end{array}$ & & $\begin{array}{l}\text { - Improved } \\
\text { relationships between } \\
\text { home and school } \\
\text { - Better understanding } \\
\text { of emergent literacy } \\
\text { - Better understanding } \\
\text { of how to provide } \\
\text { literacy-rich } \\
\text { environments }\end{array}$ \\
\hline
\end{tabular}

NGO, non-governmental organisation.

family literacy programmes, although their work includes a family literacy component (see introduction to Desmond \& Elfert 2008). As expected, there was also great diversity in respect of programme delivery methods. Using Rodgers' categories, the author's initial study in 2015 identified the programmes discussed below. A study of literature published between 2016 and 2019 revealed no new family literacy programmes, but some of the organisations had expanded their programme offerings involving early literacy learning in an informal setting. One new research study (Sibanda \& Kajee 2019) did not offer a programme but instead aimed to uncover those literacy practices that young learners engage in at home. In another study (Muzire 2018), an outcome evaluation of the Wordworks Home-School Partnership Programme was conducted.

\section{Read, Educate, Adjust, Develop Educational Trust}

Context: Read, Educate, Adjust, Develop (READ) ${ }^{1}$ Educational Trust (READ Educational Trust 2020), established in 1979, operates as an independent, non-profit organisation which relies on funding from foreign donors and the private sector.

Attributes: Operating from its head office in Johannesburg, READ has one of the largest literacy programme offerings in the country, with its focus on literacy learning in schools. The mission of READ is to develop the literacy skills of learners, and to provide support and training for language teachers. Together with provincial departments of education, the organisation selects schools to which it distributes books and language-based posters; where READ facilitators train teachers, principals and librarians and make regular monitoring visits to ensure the smooth and successful implementation of its programmes. Since its founding, READ

1.www.read.org.za 
has worked with over 2000 schools, trained over 70000 teachers and distributed some four million books to its project schools. Although no formal research is available to determine its successes, the organisation claims that learners in participating schools perform, on average, at a level up to two grades higher in reading and writing activities than learners in non-participating schools.

Apart from the various literacy offerings, only one of READ's offerings meets Rodgers' criteria for inclusion: a family literacy programme that was developed to address parents' misplaced understanding of the importance of play in preschools. The final programme comprises seven modules which are spread over 2 years (one module per term). Apart from the group sessions and discussions, parents also receive a literacy pack with stationery and an empty journal in which parents and their children can draw or write. Parents and children are invited to discuss their drawings and writing. This activity allows children to learn to distinguish between drawing and writing, and learn about the concepts of print, providing children with an opportunity to experiment with 'writing' (Levin \& Bus 2003). The family literacy programme currently runs in 36 pre-schools, mainly in the Limpopo province, with preparations well under way for it to also be implemented in the Free State (R. Els pers. comm., 13 October 2015; READ Educational Trust 2020).

Implications: Unfortunately, no information is available of the impact of the programme on literacy outcomes.

\section{The Family Literacy Project}

The Family Literacy Project ${ }^{2}$ (FLP n.d.) is not only the longestrunning project in South Africa, but also the best researched (Desmond 2008; Ntuli \& Pretorius 2005; Parry, Kirabo \& Nakyato 2014:3; Pretorius \& Machet 2004, 2008). It is also one of the programmes that best fit all of Rodgers' criteria for inclusion. It targets both adults and children through comprehensive programmes and home visits.

Context: The FLP, which was established in March 2000, serves disadvantaged communities in deep rural KwaZuluNatal (Desmond 2004:350; FLP n.d.). As an independent, non-profit organisation, it relies on donor funding from national and international organisations and the South African Government.

Attributes: Many of the households are run by women, because the men have gone elsewhere in search of work. As adult literacy levels are very low, the FLP aims to support the functional literacy needs of adults in the community. The programme teaches participants to read street names and road signs, count their money and livestock, fill out forms to receive child grants, and find their way around town (Desmond 2004:360, 2008, 2012:375). The programme uses the Regenerated Freirean Literacy through Empowering Community Techniques (REFLECT) tool that follows a participatory method of group work. Workshop topics are determined by the participants, and may include for example issues of poverty, food production and security, diseases such as HIV/AIDS, and childcare and protection (Desmond 2004:353, 2008:36). Women from the community are trained as facilitators (Desmond 2012:353).

Adult participants form the main channel through which the FLP works, and functions according to the belief that strengthening adults' literacy skills will help participants become more skilled and willing to read to their children. In the sessions, group members typically discuss the ways in which they already support their children. Parents receive an empty book to use as a journal, and in which children can draw pictures. Parents and children are encouraged to talk about their drawings and the adult motivated to write down the conversation (Desmond 2008:38). The purpose of these activities is to build participants' confidence to create opportunities that will help their children develop emergent literacy skills such as handling a book, recognising and naming letters, telling a story from the pictures and retelling the story with events in the correct sequence (Desmond 2012:352; 2008:36-37). Participants also receive home visits, the purpose of which is to share information on health and nutrition, safety in the home, common childhood illnesses and childcare in general (Desmond 2012:353-355).

Apart from the adult groups, FLP also runs weekly child-tochild programmes. The aim is not to teach children to read; rather, activities are fun-based and aim to promote a love of reading, writing, drawing and storytelling (Desmond 2008:38; 2012:353-355). The FLP has also established local libraries and trained group members to work in them. The project shares news and information through newsletters, and participants are encouraged to write letters to the editor. Various publications in the local language, isiZulu, are available and share information on issues such as raising children, helping children to develop literacy skills and general health issues. The project has published three children's books, each accompanied by an audio tape of the story (Desmond 2012:355).

Implications: There are currently 15 FLP sites (FLP n.d.; Ntuli \& Pretorius 2005:96; Pretorius \& Machet 2004:130). According to external evaluation reports, the programme is successful in establishing a culture of reading amongst participants, prompting participants to interact more fluently with children, and significantly improving children's literacy skills (Desmond 2012:356).

\section{Wordworks' Home-School Partnership Programme}

Context: Wordworks ${ }^{3}$ was established in 2005, with the aim of supporting the early language and literacy development of children from disadvantaged communities in and around the Western Cape (Wordworks 2019). As a non-governmental, non-profit organisation, it relies on donor funding.

3.www.wordworks.org.za 
Attributes: From its office in Cape Town, the organisation runs four main programmes for pre-schools, schools, libraries and community organisations (Desmond 2012:376). These programmes are the 'Early Literacy' programme, which trains volunteers to support young children's literacy learning; 'STELLAR', which provides training and resources for Grade R teachers; the 'Every Word Counts' programme, which provides parents with ideas to support their young children's language development; and the 'Home-School Partnership Programme', which supports informal literacy learning in the home.

The Home-School Partnership Programme meets all of Rodgers' categories for inclusion. It works directly with the parents and caregivers of pre-school children. During the seven sessions, Wordworks' facilitators empower parents on how to support and provide for their young children's early literacy learning at home. The Early Literacy Programme works directly with groups of young children to support their emergent reading and writing skills. Weekly activities include reading a new book, drawing and doing pretend writing, and playing word and sound games. The aim of the programme is to help families foster a culture of reading and learning and build stronger home-school and community partnerships. Partnering with provincial education departments, the three main programmes are run in over 29 schools and three libraries in the Western Cape, and in eight schools in the Eastern Cape (Desmond 2012:377-379). A number of policy briefs, together with two publications - Much more than counting: Mathematics development between birth and five years and Narrowing the literacy gap: Strengthening language and literacy development between birth and six years for children in South Africa - are available on their website (Wordworks 2019).

Implications: Both the author (Le Roux 2016) and Muzire (2018) implemented the Wordworks Home-School Partnership Programme in an effort to evaluate the role of a family literacy programme on literacy outcomes of young learners. The author's qualitative study reports strengthened funds of knowledge and social capital, improved confidence in parenting for literacy development, improved quality of parent-child interaction and raised awareness of literacy learning opportunities. Muzire's qualitative study reveals a positive improvement of learners' performance on various indicators that are related to child language and literacy development. However, Muzire cautions that the results should be interpreted with some degree of caution as the analysis was based on subjective teachers' perceptions.

\section{Project Literacy's Run Home to Read family literacy programme}

Context: Project Literacy ${ }^{4}$ was established in 1973 as a nongovernmental, non-profit organisation which aims to provide literacy learning opportunities to adults across the country (Project Literacy 2020). In 2002, the Literature Research Unit received funding from an international donor to start a project that would motivate parents with low literacy levels to read to their children. Partnering with the Department of Information Science at the University of South Africa (Unisa) (Desmond 2012:378; Machet \& Pretorius 2004:41), the 'Run Home to Read' project started with four crèches in Gauteng and extended to three more sites in KwaZulu-Natal in the following year (2001).

Attributes: The purpose of the project is to train adults with low-level literacy skills on how to read storybooks to preschool children, to enable the latter to develop the early literacy skills needed for school (Desmond 2012:378-379; Machet \& Pretorius 2004:40). This functions through the belief that, by reading to pre-school children, adult readers would gain confidence and, at the same time, have an opportunity to practise their newly acquired skills. After suitable crèches were identified, the parents were invited to attend a workshop on how to read to children. In the $4 \mathrm{~h}$ training session, parents role-played and practised reading to each other. If parents were unable to read, the text was covered and they were encouraged to tell the story from the pictures. The project also provided children's books so that the crèches could set up a small library. Children and adults were encouraged to borrow books on a regular basis (Desmond 2012:378; Machet \& Pretorius 2004:41).

Implications: The project currently runs in 16 sites across five provinces (Desmond 2012:378). Principals from the local schools reported that children who participated in the Run Home to Read programme were better prepared for formal schooling than those who did not. They were more comfortable handling books and enjoyed reading and telling their own stories. Project managers reported that parents demonstrated an increased confidence in their own reading abilities and managed to read to their children regardless of their own literacy levels. Parents also better understood their role in their child's learning and formed stronger relationships with their children. The Run Home to Read programme has received various awards, including the Mail \& Guardian Drivers of Change Award (2009) and the Silver Award of the Impumelelo Innovations Award Trust (2010). By the end of 2013, the Run Home to Read programme had reached 3400 families.

\section{The Family and Community Motivators programme}

Context: The Early Learning Resource Unit (ELRU 2017) ${ }^{5}$ is a non-governmental, non-profit organisation that strives to promote and provide access to knowledge and skills and aims to affirm and harness the potential inherent in diversity.

Attributes: The Family and Community Motivators programme was developed to empower the parents and caregivers of vulnerable young children by providing information, practical guidance and advice on child development, and suggesting activities parents and children can engage in. The programme also provides books on topics 5.www.elru.co.za 
such as health and safety, creating a stimulating learning environment, applying for social grants, and so forth. Vulnerable families receive home visits twice a month; parents are invited to various workshops; and children are organised to attend playgroups. Although it is used by many early childhood organisations, no further research on the programme is available.

Implications: Unfortunately, no information is available on the impact of the programme regarding literacy outcomes.

\section{Resource-based endeavours}

The following research-based endeavours differ from the programmes mentioned above, as they do not provide a formal comprehensive programme, nor do they offer organised formal meetings for either parents or children. They deserve a special mention as the resources target families, provide for intergenerational literacy learning opportunities and offer resources that support informal literacy learning at home. The expectation is that the resources will support families in providing environments that will nurture early literacy development, improve confidence in parenting for literacy development, improve the quality of parent-child interaction and raise awareness of literacy learning opportunities at home.

The Centre for Adult Education of the University of KwaZuluNatal (UKZN n.d.) has produced a DVD entitled 'Family literacy: Bringing literacy home', which shows real South African families from all walks of life enjoying books and literacy-related activities in their homes. The film includes footage of children who are engaged in pretend reading and pretend writing and shows home environments providing the kind of literacy practices that can help children to develop a love of books and reading.

The Project for the Study of Alternative Education in South Africa (PRAESA), an independently funded research institution (Bloch 2006; PRAESA 2020), has also produced a short film, entitled 'Feeling at home with literacy', which is available in Afrikaans and isiXhosa. The film depicts a day in the life of a young girl who is just learning to read and write, with her exploring the literacy stimuli available in her environment and showing how her mother and teachers use these resources. Together with the DG Murray Trust, PRAESA runs the highly acclaimed Nal'ibali reading-for-enjoyment campaign (Bloch 2015:2). Nal'ibali aims to re-awaken the tradition of storytelling and strives to promote a love of reading amongst adults and children. Together with local publishers, it works to transform children's opportunities to become readers and writers. To achieve its aim, Nal'ibali collaborates with libraries and reading clubs and offers materials as part of the campaign (Bloch 2015:1). To date, Nal'ibali has distributed 30 million newspaper reading supplements, circulated almost 50000 books and trained 13000 people (Nal'ibali n.d.). In August 2019, Nal'ibali was Africa's sole recipient of the Library of Congress Literacy Award.

\section{Implications and recommendation}

A further aim of this concept inquiry is to identify some implications for practice and suggest directions for future implementation. This section highlights implications for future practice.

- Clarification of the description and central concepts: Only when the nature of a concept is understood can resources, strengths and benefits be more effectively mobilised.

- Clarifying partnership attributes: Despite endorsement by educationists of the importance of parent involvement in their children's education, the role of parents in their children's literacy learning is misunderstood. Although the family has primary responsibility for the child's instruction and nurture, many parents as well as teachers believe that the development of early literacy skills should be left to the professional expertise of teachers (Gonzalez-DeHass \& Willems 2003:89). Often parents are of the view that, by reading to their children, they are infringing on the work schools should do. Parents' and teachers' attitudes and beliefs are difficult to change. For many programmes, advocacy and awareness are key to success (Rule \& Lyster 2005). Moving forward, it is important to clarify the roles and responsibilities of partners within the home - school partnership, as it means different things to different people. As is the case with the programmes discussed above, initiatives should also caution against approaches to 'fix' parents, but rather follow a wealth approach. A wealth approach requires family literacy educators and providers to acknowledge and build on literacy practices that already exist in the home. It seems that there is a balance to strike between valuing parents' contributions and at the same time not letting teachers feel threatened.

- Clarifying activity attributes: Exploring the activity attributes, it became evident that the identified programmes either fall within the comprehensive, highintensity spectrum, or are of a low-intensity nature, like the few resourced-based initiatives. The high-intensity initiatives have comprehensive programme content designed according to a theoretical framework. They focus predominantly on adult literacy and parent education (although they provide suggestions for parentchild together time), and programme activities are organised around modelling strategies by means of workshops. Significantly, the South African initiatives all target high-risk groups. Although research has found that the programme impact was greatest for high-risk groups, it also found significant effects on receptive vocabulary and language of low-risk groups. Going forward, initiatives could explore moving beyond high-risk groups to become more inclusive in nature.

- Clarifying resource attributes: Finding funding is a key problem facing many family literacy programmes. This may not only limit their influence, but also their capacity to evaluate and report. Given the current economic climate, sourcing funds may become even more challenging. Providing evidence of efficacy in terms of 
literacy outcomes may become all the more important to maintain funding support.

- Clarifying implications: As all family literacy programmes currently running in South Africa are independent and NGO-driven, hardly any formal comparative research results are available to assess these programmes' influence and efficacy. Aside from the few pioneering projects, family literacy programmes are largely regarded as a 'nice to have', rather than a tool with the potential to break the cycles of poor performance, drop-out and poverty (Rule \& Lyster 2005). To focus government and policymakers' attention on family literacy, more formal research, especially longitudinal studies, is required to adequately assess programme outcomes involving literacy performance. Research should also focus on both social-emotional domains of functioning and academic and cognitive skills.

\section{Conclusion}

When a researcher isolates a concept, it is easier to see its inner structure. Rodgers' approach proved helpful for developing knowledge about family literacy and the family literacy programmes designed to support early literacy learning of young South African learners. The framework provided clarification of the description and central concepts. Identification of the attributes of family literacy programmes assisted with the identification of a few high-intensity and additionally some low-intensity programmes running in South Africa. The lack of data to demonstrate the implications of family literacy programmes for literacy outcomes also become evident. This gap indicates a need for more formal longitudinal studies to quantify the impact such programmes may have on literacy outcomes. Taking the current economic climate into account, maintaining funding support may become even more challenging in the absence of clear research outcomes. In conclusion, if family literacy programmes are to gain momentum, researchers must continue to unpack what this concept holds to ensure that such programmes yield optimal results for participating families as well as the South African schooling system.

\section{Acknowledgements Competing interests}

The author has declared that no competing interests exist.

\section{Author's contributions}

I declare that I am the sole author of this research article.

\section{Ethical considerations}

The application was reviewed in compliance with the University of South Africa Policy on Research Ethics by the College of Education Research Ethics Review Committee on 10 September 2014 (2014 September/32068336/MC).
The proposed research may now commence with the proviso that:

- The researcher(s) will ensure that the research project adheres to the values and principles expressed in the UNISA Policy on Research Ethics.

- Any adverse circumstance arising in the undertaking of the research project that is relevant to the ethicality of the study, as well as changes in methodology, should be communicated in writing to the College of Education Ethics Review Committee. An amended application could be requested if there are substantial changes from the existing proposal, especially if those changes affect any of the study-related risks for the research participants.

- The researcher will ensure that the research project adheres to any applicable national legislation, professional codes of conduct, institutional guidelines and scientific standards relevant to the specific field of study.

Chairperson CEDU RERC: Dr M Claassens, Acting Executive Dean: Prof VI McKay.

\section{Funding information}

This research received no specific grant from any funding agency in the public, commercial or not-for-profit-sectors.

\section{Data availability statement}

Data sharing is not applicable to this article as no new data were created or analysed in this study.

\section{Disclaimer}

The views and opinions expressed in this article are those of the author and do not necessarily reflect the official policy or position of any affiliated agency of the author.

\section{References}

Alexander, N., 2005, 'Key issues in language policy for Southern Africa', in R. Trewby \& S. Fitchat (eds.), Language and development in Southern Africa: Making the right choices, pp. 9-22, Gamsberg Macmillan, Windhoek.

Amoateng, A.Y. \& Richter, L., 2003, 'The state of families in South Africa', in A. Daniel, A. Habib \& R. Southall (eds.), State of the nation: South Africa 2003-2004, pp. 242-267, Human Sciences Research Council Press, Pretoria.

Berns, R.M., 2016, Child, family, school, community: Socialisation and support, 10th edn., Cengage, Stanford, CA

Bloch, C., 2006, 'Theory and strategy of early literacy in contemporary Africa with special reference to South Africa', Unpublished summary paper presented to the Faculty of Education, Carl von Ossietzky Universität, Oldenburg.

Bloch, C., 2015, Nal'ibali and libraries: Activating the gift of reading together, viewed 11 October 2015, from https://creativecommons.org/licences/by/3.0.

Cohen, M., 2017, SA spends higher proportion of budget on education than US, UK, 5 January 2017, viewed 10 September 2019, from https://www.fin24.com/ Economy/sa-spends-more-on-education-than-us-uk-and-germany-20170105.

Crawford, P.A. \& Zygouris-Coe, V., 2006, 'All in the family: Connecting home and school with family literacy', Early Childhood Education Journal 33(4), 261-267. https:// doi.org/10.1007/s10643-005-0047-x

Desmond, D. \& Elfert, M., 2008, 'Foreword', in S. Desmond \& M. Elfert (eds.), Family literacy: Experiences from Africa and around the world, pp. vi-vii, UNESCO, Paris.

Desmond, S., 2004, 'Literacy for now and for the future: Working with parents and children', Language Matters 35(2), 348-362. https://doi.org/10.1080/ 10228190408566222

Desmond, S., 2008, 'Family literacy in a rural setting: The story of the family literacy project', in S. Desmond \& M. Elfert (eds.), Family literacy: Experiences from Africa and around the world, pp. 33-40, UNESCO, Paris. 
Desmond, S., 2012, 'Family literacy programmes in South Africa', in B.H. Wasik (ed.), Handbook of family literacy, Routledge, London.

Early Learning Resource Unit (ELRU), 2017, ELRU, viewed 17 December 2019, from www.elru.co.za.

Family Literacy Project (FLP), n.d., Family Literacy Project: Promoting a love for reading, viewed 10 February 2020, from https://www.familyliteracyproject.co.za/.

Gonzalez-DeHass, A.R. \& Willems, P.P., 2003, 'Examining the underutilization of parent involvement in the schools', School Community Journal 13(1), 85-99.

Hannon, P. \& Bird, V., 2004, 'Family literacy in England: Theory, practice, research and policy', in B.H. Wasik (ed.), Handbook of family literacy, pp. 23-44, Lawrence policy', in B.H. Wasik
Erlbaum, Mahwah, NJ.

Holborn, L. \& Eddy, G., 2011, First steps to healing the South African family, South African Institute of Race Relations, Johannesburg, viewed 24 October 2013, from https://irr.org.za/reports-and-publications/occasional-reports/files/first-steps-toheltps://irr.org.za/reports-and-publications/occasional-reports/

Howie, S., Combrinck, C., Roux, K., Tshele, M., Mokoena, G. \& McLeod Palane, N., 2017, 'Progress in international reading literacy study 2016: South African children's reading literacy achievement', Summary report, Centre for Evaluation and Assessment, Pretoria.

Jay, J. \& Rohl, M., 2005, 'Constructing a family literacy programme: Challenges and successes', International Journal for Early Childhood 37(1), 57-78.

Keyser, J., 2006, From parents to partners: Building a family-centered program, Redleaf Press, New York, NY.

Le Roux, S.G., 2016, The role of family literacy programmes to support emergent literacy in young learners, D.Ed thesis, University of South Africa, Pretoria.

Lemmer, E. \& Van Wyk, N., 2007, 'Parent involvement in education', in C.C. Wolhuter E.M. Lemmer \& N.C. de Wet (eds.), Comparative education: Education systems and contemporary issues, pp. 195-206, Van Schaik, Pretoria.

Lemmer, E.M., 2013, 'The parent-teacher relationship as partnership: A conceptual analysis', Journal for Christian Scholarship 49(1\&2), 25-54.

Levin, I. \& Bus, A.G., 2003, 'How is emergent writing based on drawing? Analysis of children's products and their sorting by children and mothers', Developmental Psychology 39(5), 891-905. https://doi.org/10.1037/0012-1649.39.5.891

Locke, J., 2000, Some thoughts concerning education, Clarendon Press, Oxford (Original work published in 1693).

Machet, M. \& Pretorius, E.J., 2004, 'Family literacy: A project to get parents involved' South African Journal for Library and Information Science 70(1), 39-46. https:// doi.org/10.7553/70-1-694

McNulty, L., 2014, 'Locke, John', in D.C. Phillips, Encyclopaedia of educational theory and philosophy, vol. 2, pp. 492-495, SAGE, Thousand Oaks, CA.

Mulgrew, N., 2012, 'Literacy: Once upon a time, parents taught their children to read' Mail \& Guardian, 19 October 2012, viewed 21 October 2013, from https://mg. co.za/print/2012-10-19-00-once-upon-a-time-parents-taught.

Muzire, M., 2018, An outcome evaluation of the home-school partnership programme, University of Cape Town, Cape Town.

Nal'ibali, n.d., Nal'ibali: it starts with a story, viewed 08 October 2019, from https:// nalibali.org/.

Neaum, S., 2012, Language and literacy for the early years, SAGE, London.

Ntuli, D. \& Pretorius, E.J., 2005, 'Laying foundations for academic language competence: The effects of storybook reading on Zulu language, literacy and discourse development', Southern African Linguistics and Applied Language discourse development', Southern African Linguistics and Applied
Studies 23(1), 91-109. https://doi.org/10.2989/16073610509486376

Parcel, T.L., Dufur, M.J. \& Zito, R.C., 2010, 'Capital at home and school: A review and synthesis', Journal of Marriage and Family 72(4), 828-846. https://doi. org/10.1111/j.1741-3737.2010.00733.x

Parry, K., Kirabo, E. \& Nakyato, G., 2014, 'Working with parents to promote children's literacy: A family literacy project in Uganda', Multilingual Education 4(13), 1-15. https://doi.org/10.1186/s13616-014-0013-2

Postma, M. \& Postma, D., 2011, 'Who is laughing last in the South African classroom? A critical reflection on language in education', Southern Africa Linguistics and Applied Language Studies 29(1), 43-64. https://doi.org/10.2989/16073614.2011.583156

PRAESA, 2020, Praesa: growing biliteracy and multilingualism, viewed 12 February 2020, from www.praesa.org.za.

Pretorius, E. \& Machet, M.P., 2004, 'Literacy and disadvantage: Learners' achievements in the early primary school years', Africa Education Review 1(1), 128-146. https:// doi.org/10.1080/18146620408566274

Pretorius, E. \& Machet, M.P., 2008, 'The impact of storybook reading on emergent literacy: Evidence from poor rural areas in KwaZulu-Natal, South Africa', Mousaion (Special Issue) 26(2), 261-289.

Pretorius, E.J., 2014, 'Supporting transition or playing catch-up in Grade 4? Implications for standards in education and training', Perspectives in Education 32(1), 51-76.
Project Literacy, 2020, Leaders in adult learning, viewed 12 February 2020, from https://www.projectliteracy.org.za/.

Rama, S. \& Richter, L.M., 2007, 'Children's household work as a contribution to the well-being of the family and household', in A.Y. Amoateng \& T.B. Heaton (eds.), Families and households in post-apartheid South Africa: Socio-demographic perspectives, pp. 135-170, Human Science Research Council Press, pp. 135-170, Cape Town.

READ Educational Trust, 2020, READ Educational Trust, viewed 12 February 2020, from https://www.read.org.za/.

Republic of South Africa (RSA), 1996, 'Constitution of the Republic of South Africa, Act 108 of 1996', in Government Gazette, vol. 378, no. 17678, President's Office, Government Printers, Pretoria.

Republic of South Africa (RSA), 2019a, Highlights of the State of the Nation address, viewed 10 September 2019, from https://www.gov.za/sites/default/files/gcis_ document/SoNA\%2OHighlights-FINAL.pdf.

Republic of South Africa (RSA), 2019b, Minister Angie Motshekga: Education budget vote speech 2018/19, viewed 10 October 2019, from https://www.gov.za/ speeches/minister-angie-motshekga-basic-education-dept-budget-vote-2018199-may-2018-0000.

Rodgers, B.L., 2000, 'Concept analysis', in B.L. Rodgers \& K.A. Knafl (eds.), Concept development in nursing, 2nd edn., pp. 77-102, Saunders, Philadelphia, PA.

Rule, P. \& Lyster, E., 2005, 'Keeping it in the family: Exploring relations between family literacy, early childhood development and adult basic education', Paper presented
at the 'Bringing literacy home conference', held by the Centre for Adult Education, at the 'Bringing literacy home conference', held by the Centre for Adu
19-21 September, University of KwaZulu-Natal, Pietermaritzburg.

Sibanda, R. \& Kajee, L., 2019, 'Home as a primary space: Exploring out-of-school literacy practices in early childhood education in a township in South Africa', South African Journal of Childhood Education 9(1), a686. https://doi.org/10.4102/sajce.v9i1.686

Simkins, C., 2013, 'Performance of the South African educational system: What do we know?', Report commissioned by the Centre for Development and Enterprise,
viewed 20 September 2015, from https://www.cde.org.za/wp-content/ viewed 20 September 2015, from https://wwW.cde.org.za/wp-content/
uploads/2013/10/Performance $\% 20$ in $\% 20$ the $\% 20$ South $\% 20$ African $\% 20$ uploads $/ 2013 / 10 /$ Performance $\% 20$ in $\% 20$ th $\%$.

Spaull, N. \& Taylor, S., 2012, 'Effective enrolment - Creating a composite measure of educational access and educational quality to accurately describe education system performance in sub-Saharan Africa', Stellenbosch Economic Working Papers 21/12, November, pp. 1-25, University of Stellenbosch, Stellenbosch.

Statistics South Africa (Stats SA), 2013, South Africa's young children: Their family and home environment, 2012, Stats SA, Pretoria.

Statistics South Africa (Stats SA), 2019, Unemployment rises slightly in third quarter of 2019, viewed 05 December 2019, from www.statssa.gov.za

Taylor, S., 2017, 'How context mediates the effectiveness of teacher support interventions: Evidence from a multi-arm randomised experiment in South Africa", Paper submitted for the Economics Society of South Africa (ESSA) conference of 2017, viewed 17 April 2020, from https://www.google.com/search?q=how+conte $\mathrm{xt}+$ mediates+the+effectiveness+of+teacher+support\&rlz=1C1GCEU enZA872ZA $872 \&$ oq $=$ how+context+mediates+the+effectiveness+of+teacher+support\&aqs $=c$ hrome..69i57.15923j0j8\&sourceid=chrome\&ie=UTF-8.

Tofthagen, R. \& Fagerstrom, L.M., 2010, 'Rodgers' evolutionary concept analysis', Scandinavian Journal of Caring Sciences 24(suppl 1), 21-31. https://doi.org/ 10.1111/j.1471-6712.2010.00845.x

Train, B., 2007, 'Research on family literacy: An international perspective', Library Review 56(4), 292-298. https://doi.org/10.1108/00242530710743516

University of KwaZulu-Natal (UKZN), n.d., Centre for adult education, viewed 12 February 2020, from https://cae.ukzn.ac.za/Resources/FamLit.aspx.

University of South Africa (UNISA), 2008, 'A situational analysis of child-headed households in South Africa', Report on research conducted by the University of South Africa, Unisa, Pretoria.

Van der Berg, S., Girdwood, E., Shepherd, D., Van Wyk, C., Kruger, J., Viljoen, J. et al . 2013, The impact of the introduction of Grade $R$ on learning outcomes, Report compiled by the University of Stellenbosch, Stellenbosch.

Van der Berg, S., Taylor, S., Gustafsson, M., Spaull, N. \& Armstrong, P., 2011, 'Improving education quality in South Africa', Report for the National Planning Commission, September 2011, Dept. of Economics, University of Stellenbosch, Stellenbosch September 2011, Dept. of Economics, University of Stellenbosch, Stellenbosch,
viewed 20 September 2015, from https://resep.sun.ac.za/wp-content/uploads/ viewed 20 September 2015, from

Wasik, B.H. \& Hermann, S., 2004, 'Family literacy: History, concepts, services', in B.H. Wasik (ed.), Handbook of family literacy, pp. 3-22, Lawrence Erlbaum, Mahwah, NJ.

Wasik, B.H., Dobbins, D.R. \& Hermann, S., 2001, 'Intergenerational family literacy: Concepts, research and practice', in S.B. Neuman \& D.K. Dickinson (eds.) Concepts, research and practice', in S.B. Neuman \& D.K. Dickinson (eds.),
Handbook of early literacy research, pp. 444-458, Guilford Press, New York, NY.

Wordworks, 2019, Wordworks: Changing lives through literacy, viewed 18 December 2019, from https://wordworks.org.za/. 